URL: journal.unesa.ac.id/index.php/jram

\title{
ANALISIS MODEL PREDATOR-PREY LESLIE-GOWER DENGAN PEMBERIAN RACUN PADA PREDATOR
}

\author{
Siti HARDIYANTI ARSYAD ${ }^{1}$, RESMAWAN $^{2}$, NOVIANITA ACHMAD ${ }^{3}$ \\ 1,2,3 Jurusan Matematika, Fakultas MIPA, Universitas Negeri Gorontalo \\ * sitihardiyantiarsyad00@gmail.com
}

\begin{abstract}
ABSTRAK
Penelitian ini membahas tentang model predator-prey dengan asumsi pemberian racun pada predator. Interaksi antara predator-prey menggunakan fungsi respons Holling tipe II. Pertumbuhan predatorprey menggunakan fungsi logistik. Dinamika model di sekitar titik kesetimbangan dipengaruhi oleh kestabilan dari titik kesetimbangan. Dari model tersebut diperoleh dua titik kesetimbangan model, yaitu titik kesetimbangan kepunahan predator dan titik kesetimbangan interior. Titik kesetimbangan kepunahan pada predator selalu tidak stabil dalam kondisi apapun, sedangkan titik kesetimbangan interior dapat mencapai kondisi stabil dengan beberapa syarat. Pada bagian akhir, diberikan simulasi numerik untuk menunjukkan parameter efektivitas pemberian racun pada predator.
\end{abstract}

Kata Kunci: Predator-Prey, Leslie-Gower; Racun; Titik Kesetimbangan

\begin{abstract}
This study discusses a predator-prey model assuming poison is given to predators. The interaction between predators uses a type II Holling functional response. Growth of predator-prey using logistics function. The dynamics of the model around the equilibrium point is influenced by the stability of the equilibrium point. From the model acquired two equilibrium points of the model, namely the equilibrium points of the extinction of the predator and the equilibrium point of the interior. The extinction point in the predator is always unstable under any circumstances, while the equilibrium point of the interior can achieve a stable condition with some conditions. At the end, it was given a numerical simulation to demonstrate the effectiveness parameters of poison feeding on predators.
\end{abstract}

Keywords: Predator-Prey, Leslie-Gower; Toxins, Equilibrium Point

\section{Pendahuluan}

Setiap makhluk hidup dituntut untuk senantiasa berinteraksi dengan makhluk hidup lainnya. Interaksi yang terjadi antara individu dalam satu spesies atau interaksi antara individu dengan spesies yang berbeda dapat berdampak positif bagi keduanya, berdampak negatif bagi keduanya maupun berdampak negatif bagi salah satu spesies dan positif bagi spesies yang lain. Jika berdampak positif bagi keduanya, interaksi keduanya disebut simbiosis mutualisme. Jika berdampak negatif bagi keduanya disebut persaingan, dan jika berdampak positif bagi spesies 
yang satu sedangkan bagi spesies yang lainnya negatif maka interaksi tersebut disebut dengan mangsa-pemangsa atau prey-predator [1].

Model predator-prey adalah objek kajian yang sangat menarik untuk dipelajari dalam bidang matematika ekologi karena menyangkut eksistensi dari satu atau lebih spesies. Model ini sangat popular yang dibuktikan dengan banyaknya penelitian yang mempelajari model ini. Batasan dari model ini sangatlah luas sehingga banyak peneliti melakukan modifikasi dan mengembangkan model predator-prey dengan harapan model tersebut bersesuaian dengan kondisi mangsa-pemangsa yang ada di alam [2]. Pada tahun 1948, Leslie dan Gower melakukan modifikasi pada sistem Lotka-Volterra. Populasi predator yang awalnya bertumbuh secara eksponensial dengan adanya pengaruh predasi dimodifikasi menjadi bertumbuh secara logistik dengan asumsi bahwa daya dukung lingkun- gan predator proporsional terhadap jumlah populasi prey, dan model yang diperoleh dari modifikasi tersebut dikenal dengan model Leslie-Gower [3]. Populasi mangsa mempunyai persediaan makanan yang tersedia cukup di dalam lingkungannya, sedangkan pada populasi pemangsa memiliki makanan yang bergantung pada jumlah mangsa. Apabila populasi mangsa terbatas maka untuk populasi pemangsa akan menurun sesuai dengan jumlah proporsi mangsanya [4].

Beberapa penelitian telah membahas modifikasi model predator-prey diantaranya Afiyah [1] membahas tentang model predator-prey Leslie-Gower dengan fungsi respon Holling tipe II. Selanjutnya Keong dkk [5] membahas model predator-prey dengan pemanenan dan adanya pengaruh racun pada kedua populasi. Hasan, dkk [6] juga membahas topik serupa dengan pemanenan kontan pada predator. Penelitian terbaru dilakukan oleh Panigoro, dkk [7] yang membahas tentang model Leslie-Gower. Adapun dalam tulisan ini dipertimbangkan adanya peran manusia dalam eksistensi predator dan prey. Dalam suatu lingkungan yang memperlihatkan adanya interaksi antara predator dan prey, misalnya di lingkungan peternakan yang terdapat predator-prey dengan prey terancam punah karena adanya predator. Oleh karena itu, dalam makalah ini dibahas tentang model predator-prey Leslie-Gower dengan pemberian racun pada predator. Model diperoleh menunjukkan untuk menganalisis kestabilan sistem.

\section{Tinjauan Pustaka}

\subsection{Sistem Persamaan Differensial}

Sistem persamaan diferensial orde satu dengan $n$ fungsi tak diketahui yaitu $x_{1}, x_{2}, \ldots, x_{n}$ dapat ditulis

$$
\begin{gathered}
\frac{d x_{1}}{d t}=f_{1}\left(t, x_{1}, x_{2}, \ldots, x_{n}\right) \\
\frac{d x_{2}}{d t}=f_{2}\left(t, x_{1}, x_{2}, \ldots, x_{n}\right) \\
\vdots \\
\frac{d x_{n}}{d t}=f_{n}\left(t, x_{1}, x_{2}, \ldots, x_{n}\right)
\end{gathered}
$$

dengan $f_{i}$ adalah fungsi kontinu pada $[a, b]$, untuk $i=1,2, \ldots, n[8]$.

\subsection{Titik Kesetimbangan}

Misalkan sistem persamaan diferensial dinyatakan

$$
\dot{x}=f(x), \quad x \in R^{n}
$$




\section{Definisi 1}

Titik $\bar{x} \in R^{n}$ disebut titik kesetimbangan dari persamaan (1) jika $f(\bar{x})=0$ [9].

\section{Definisi 2}

Titik kesetimbangan $\bar{x} \in R^{n}$ pada system (1), berlaku:

1) Jika untuk setiap $\varepsilon>0$ terdapat $\delta>0$ sedemikian hingga untuk setiap solusi $x(t)$ yang memenuhi $\left\|x\left(t_{0}\right)-\bar{x}\right\|<\delta$ berlaku $\|x(t)-\bar{x}\|<\varepsilon$ untuk setiap $t \geq t_{0}$ maka $\bar{x} \in R^{n}$ stabil lokal.

2) Jika titik kesetimbangan $\bar{x} \in R^{n}$ stabil dan terdapat $\delta_{0}>0$ sedemikian hingga untuk setiap solusi $x(t)$ yang memenuhi $\left\|x\left(t_{0}\right)-\bar{x}\right\|<\delta_{0}$ berlaku $\lim _{t \rightarrow \infty} x(t)=\bar{x}$ maka $\bar{x} \in$ $R^{n}$ stabil asimtotik lokal.

3) Jika titik kesetimbangan $\bar{x} \in R^{n}$ tidak memenuhi poin [1] maka $\bar{x} \in R^{n}$ tidak stabil [10].

\subsection{Linearisasi}

Linierisasi merupakan proses metransformasi sistem persamaan diferensial yang nonlinear kebentuk persamaan diferensial yang linier. Analisis kestabilan dapat dilakukan dengan pelinieran, untuk mencari hasil pelinieran dari sistem persamaan diferensial tak linear digunakan matriks jacobi.

\section{Definisi 3}

Diberikan fungsi $f=\left(f_{1}, f_{2}, \ldots, f_{n}\right)$ pada sistem $\dot{x}=f(x)$ dengan $f_{i} \in C(E), i=1,2, \ldots, n$. Diberikan matriks jacobian dari $f$ di titik $\bar{x}$ sebagai berikut:

$$
J f(\bar{x})=\left[\begin{array}{cccc}
\frac{\partial f_{1}}{\partial x_{1}}(\bar{x}) & \frac{\partial f_{1}}{\partial x_{2}}(\bar{x}) & \ldots & \frac{\partial f_{1}}{\partial x_{n}}(\bar{x}) \\
\frac{\partial f_{2}}{\partial x_{1}}(\bar{x}) & \frac{\partial f_{2}}{\partial x_{2}}(\bar{x}) & \ldots & \frac{\partial f_{2}}{\partial x_{n}}(\bar{x}) \\
\vdots & \vdots & \ddots & \vdots \\
\frac{\partial f_{n}}{\partial x_{1}}(\bar{x}) & \frac{\partial f_{n}}{\partial x_{2}}(\bar{x}) & \ldots & \frac{\partial f_{n}}{\partial x_{n}}(\bar{x})
\end{array}\right]
$$

\section{Definisi 4}

Sistem linear $\dot{x}=J f(\bar{x})(x-\bar{x})$ dikatakan linearisasi sistem non-linear $\dot{x}=f(x)$ disekitaran titik $\bar{x}[11]$.

\subsection{Nilai Eigen dan Vektor Eigen}

Jika $A$ merupakan matriks $n \times n$, maka ada vektor taknol $x$ di dalam $R^{n}$ disebut vektor eigen dari $A$, jika $A x$ merupakan sebuah kelipatan skalar dari $x$ maka

$$
A x=\lambda x
$$

untuk suatu skalar $\lambda$. Skalar $\lambda$ disebut nilai eigen dari $A$, dan $x$ disebut sebagai vektor eigen dari $A$. [11] 


\subsection{Analisis Kestabilan}

Kestabilan titik kesetimbangan dapat ditentukan dengan mencari nilai eigen yaitu $\lambda_{i}$ dengan $i=1,2,3, \ldots, n$ yang didapatkan dari penyelesaian matriks tak nol yang berukuran $n \times n$. Misalkan $A$ adalah matriks yang berukuran $n \times n$ dan $I$ adalah matriks identitas yang berukuran $n \times n$, maka nilai eigen dari matriks $A$ mempunyai solusi taknol jika dan hanya jika

$$
\operatorname{det}(A-\lambda I)=0
$$

Secara umum titik kesetimbangan mempunyai sifat sebagai berikut:

1) Akan stabil jika

a) Setiap nilai eigen real negatif maka $\lambda_{i}<0$ untuk setiap $i$, atau

b) Terdapat $\operatorname{Re}\left(\lambda_{i}\right)=0$ untuk sebarang $j$ dan nilai eigen kompleks bagian real $\operatorname{Re}\left(\lambda_{i}\right)<0$ untuk setiap $i \neq j$.

2) Tidak stabil jika

a) Terdapat paling sedikit nilai eigen real positif maka $\lambda_{i}>0$ untuk setiap $i$.

b) Terdapat paling sedikit nilai eigen kompleks bagian real $\operatorname{Re}\left(\lambda_{i}\right)>0$ untuk setiap $i$ [12].

\subsection{Model Predator-Prey}

Ada beberapa jenis interaksi mangsa dan pemangsa seperti herbivora yang memakan jenis tanaman, karnivora memakan spesies hewan, parasit yang hidup pada atau di spesies lain dan kanibal yang makan spesies pemangsa dan satu spesies mangsa.

Interaksi yang terjadi antara mangsa dan pemangsa akan mengakibatkan terjadinya proses makan dan dimakan yang berpengaruh terhadap kepadatan populasi masing-masing. Model predator- prey dituliskan pada system persamaan digerensial (2),

$$
\begin{aligned}
& \frac{d P}{d t}=r P\left(1-\frac{P}{K}\right)-\beta P X \\
& \frac{d X}{d t}=\beta P X-\varphi X
\end{aligned}
$$

dengan $P$ dan $X$ masing-masing menyatakan kepadatan populasi prey dan predator, sedangkan $K, \beta, r, \varphi$ berturut-turut menyatakan carrying capacity, tingkat interaksi predatorprey, laju pertumbuhan prey, serta tingkat kematian predator. Diasumsikan $K, \beta, r, \varphi>0$ karena setiap populasi berpotensi berkembang biak [13].

\subsection{Model Leslie-Gower}

Pada tahun 1948, Leslie dan Gower memperkenalkan model dengan populasi predator tumbuh mengikuti model logistik sehingga pertumbuhannya terbatas. Selain itu, laju pertumbuhan predator sebanding dengan banyaknya populasi prey. Sehingga jika dinotasikan $x(t)$ sebagai kepadatan populasi prey dan $y(t)$ merupakan kepadatan populasi predator maka model Leslie-Gower diberikan dalam bentuk sistem persamaan differensial (3),

$$
\dot{x}=\left(r_{1}-c_{1} y-b_{1} x\right) x
$$




$$
\dot{y}=\left(r_{2}-c_{2} \frac{y}{x}\right) y
$$

dengan $x, y$ adalah variabel yang bergantung pada $t$, sedangkan $b_{1}, c_{1}, c_{2}, r_{1}$, dan $r_{2}$ adalah konstanta positif [14].

\subsection{Fungsi Respon}

Fungsi respon dalam ekologi adalah jumlah makanan yang dimakan oleh predator sebagai fungsi kepadatan makanan. Dalam hal ini fungsi respon dibagi atas tiga macam, yaitu fungsi respon holling tipe I, tipe II, dan tipe III.

\subsubsection{Holling Tipe I}

Fungsi respon holling tipe I merupakan hubungan dengan tingkat konsumsi. Tingkat konsumsi predator meningkat linear dengan kepadatan prey, tetapi akan konstan ketika predator berhenti memangsa. Peningkatan linear mengasumsikan bahwa waktu yang dibutuhkan oleh konsumen untuk memproses pokok makanan diabaikan, atau bahwa mengkonsumsi makanan tidak mengganggu pencarian makanan. Fungsi respon holling tipe I terjadi pada predator yang memiliki karakteristik pasif, atau lebih suka menunggu preynya, sebagai contoh predatornya adalah laba-laba. Fungsi respon holling tipe I adalah fungsi respon pertama yang dijelaskan dan juga yang paling sederhana dari tiga fungsi respon yang ada saat ini. Adapun tingkat pertumbuhan mangsa pada model fungsi respon holling tipe I diberikan

$$
F^{(I)}(x)=a x
$$

dengan $F^{(I)}$ menyatakan fungsi holling tipe I, a menyatakan tingkat konsumsi maksimum predator terhadap prey, dan $x$ menyatakan jumlah populasi mangsa [15].

\subsubsection{Holling Tipe II}

Pada model holling tipe II, terlihat bahwa rata-rata tingkat konsumsi dari predator, ketika predator menghabiskan waktu untuk mencari prey. Fungsi respon tipe II terjadi pada predator yang berkarakteristik aktif dalam mencari prey, sebagai contoh predator -nya adalah serigala. Fungsi ini akan meningkat jika tingkat konsumsi menurun dan akan konstan jika mencapai titik kejenuhan (half saturation). Hal ini disebabkan setiap pemangsa hanya dapat memakan sejumlah mangsa pada saat satu satuan waktu. Adapun tingkat pertumbuhan mangsa pada model holling tipe II ditulis pada persamaan (4),

$$
F^{(I I)}(x)=\frac{a x}{1+b x}
$$

dengan $F^{(I I)}$ menyatakan fungsi holling tipe II, a tingkat konsumsi maksimum predator terhadap prey, $b$ menyatakan waktu pencarian prey, dan $x$ menyatakan jumlah populasi mangsa [16].

\subsubsection{Holling Tipe III}


Model holling tipe III juga menggambarkan tingkat pertumbuhan pemangsa. Tetapi pada model ini dapat terlihat mengenai penurunan tingkat pemangsaan pada saat kepadatan mangsa rendah. Hal tersebut tidak dapat terlihat pada model holling tipe III. Fungsi respon holling tipe III terjadi pada predator yang cenderung akan mencari populasi prey yang lain ketika populasi prey yang dimakan mulai berkurang. Karena predator yang cenderung akan mencari populasi prey yang lain, maka tingkat pertemuan antara predator dan prey adalah dua. Hal inilah yang menyebabkan variabel populasi prey menjadi $N^{2}$, sehingga laju populasi menjadi lebih cepat. Adapun tingkat pertumbuhan mangsa pada model holling tipe III ditulis

$$
F^{(I I I)}(x)=\frac{a x^{2}}{1+b x^{2}}
$$

dengan $F^{(I I I)}$ menyatakan fungsi holling tipe III, a tingkat konsumsi maksimum predator terhadap prey, $b$ menyatakan tingkat kejenuhan pemangsaan, dan $x$ menyatakan jumlah populasi mangsa [17].

\section{Metode}

\subsection{Metode Penelitian}

Penelitian ini didahului dengan studi literatur terkait sistem dinamik dan model predator-prey. Studi literatur adalah kegiatan menelusuri dan mempelajari sejumlah buku, text-book, jurnal, ataupun artikel yang berhubungan dengan fokus penelitian untuk dijadikan rujukan. Setelah dilakukan studi literatur, diperoleh beberapa asumsi sebagai berikut.

1. Predator-prey bertumbuh secara logistik.

2. Model yang digunakan fungsi respon Holling tipe II.

3. Pemberian racun hanya berpengaruh pada predator.

\subsection{Tahapan Penelitian}

Adapun tahapan-tahapan dan prosedur penelitian adalah sebagai berikut.

1. Penelusuran jurnal dan referensi.

Tahap paling awal pada penelitian ini yaitu melakukan penelusuran beberapa referensi dan artikel yang berkaitan dengan fokus penelitian. Dari hasil penelusuran beberapa referensi dan artikel, model Leslie-Gower dipilih untuk dijadikan objek penelitian.

2. Penentuan asumsi

Setelah ditemukan model yang akan diteliti, ditentukan beberapa asumsi yang akan digunakan.

3. Modifikasi model

Setelah ditentukan asumsi, model dimodifikasi berdasarkan asumsi yang ada.

4. Penskalaan model

Pada tahapan ini, dilakukan penskalaan pada model untuk memudahkan proses analisis.

5. Mencari titik kesetimbangan.

6. Menganalisis dinamika model di sekitar titik kesetimbangan.

7. Simulasi numerik

Pada tahapan ini, dibuat simulasi numerik dari model. Untuk keperluan simulasi numerik, digunakan aplikasi Phyton versi 3.7.3150.0.

8. Interpretasi dan kesimpulan

Hasil simulasi numerik model diinterpretasi kemudian berdasarkan hasil analisis dan interpretasi simulasi numerik, disimpulkan hasil tujuan penelitian. 


\section{Hasil dan Pembahasan}

Model yang digunakan pada tulisan ini mengacu pada persamaan (2) dan (3) dengan menggunakan fungsi respon tipe II pada persamaan (4). Selain itu diterapkan penggunaan racun pada predator $(\beta)$ sehingga diperoleh model sebagai berikut:

$$
\begin{aligned}
& \dot{x}=r x\left(1-\frac{x}{k}\right)-\frac{a x y}{1+h \alpha x} \\
& \dot{y}=s y\left(1-\frac{y}{n x}\right)-\beta y
\end{aligned}
$$

dengan $x$ dan $y$ masing-masing menyatakan kepadatan populasi prey dan predator, sedangkan $r, s, k, n x, \alpha, h, \beta$ berturut-turut menyatakan laju pertumbuhan intrinsik prey, laju pertumbuhan intrinsik predator, keterbatasan daya dukung lingkungan prey, keterbatasan daya dukung lingkungan predator, tingkat pencarian dan penangkapan prey oleh predator, tingkat penanganan dan pencernaan predator, serta efektivitas racun.

\subsection{Penskalaan}

Sebelum mencari titik kesetimbangan, terlebih dahulu dilakukan penskalaan terhadap model (4) ke dalam bentuk yang lebih sederhana tanpa mengubah model sistem persamaan. Penskalaan model akan memangkas beberapa parameter. Penskalaan dapat dilakukan karena tidak merubah skala pengukuran [18]. Dengan melakukan penskalaan $(x, y, t) \rightarrow$ $\left(h \alpha x, \frac{\alpha}{r} y, r t\right)$, model (4) tereduksi menjadi,

$$
\begin{aligned}
& \dot{x}=x\left(1-\frac{x}{\mu}\right)-\frac{x y}{1+x} \\
& \dot{y}=\eta y\left(1-\frac{\sigma y}{x}\right)-\xi y
\end{aligned}
$$

dengan

$$
\mu=\alpha h k, \quad \sigma=\frac{r h}{n}, \quad \eta=\frac{s}{r}, \quad \xi=\frac{\beta}{r}, \quad \alpha, \beta, h, k, n, r, s>0
$$

\subsection{Titik Kesetimbangan}

Titik kesetimbangan model pada persamaan (5) diperoleh pada saat $\dot{x}=\dot{y}=0$, sehingga dapat ditulis,

$$
\begin{aligned}
& x\left(1-\frac{x}{\mu}\right)-\frac{x y}{1+x}=0 \\
& \eta y\left(1-\frac{\sigma y}{x}\right)-\xi y=0
\end{aligned}
$$

Dari persamaan (6) diperoleh dua titik kesetimbangan, yaitu:

$$
E_{0}(\mu, 0) \text { dan } E_{1}\left(x^{*}, y^{*}\right)
$$

dengan 


$$
\begin{aligned}
x^{*} & =\frac{-A \pm \sqrt{A^{2}-4 \mu}}{2} ; y^{*}=\frac{\eta-\xi}{\eta \sigma} x^{*} \\
A & =\frac{\mu \eta+\sigma \eta-\mu \xi-\mu \sigma \eta}{\sigma \eta}
\end{aligned}
$$

\subsection{Eksistensi Titik Kesetimbangan}

Berdasarkan kondisi biologis di alam, jumlah populasi spesies tak negatif, maka solusi dari persamaan (6) harus tak negatif. Eksistensi titik kesetimbangan dari (6) dinyatakan sebagai berikut:

(i) $E_{0} \in R^{+}$, maka $E_{0}$ adalah titik ekuilibrium.

(ii) $E_{1}$ adalah titik ekuilibrium jika $A^{2}-4 \mu \geq 0$

a) $A^{2}-4 \mu>0$

Jika $A^{2}-4 \mu \geq 0$, maka $\sqrt{A^{2}-4 \mu}>0$. Akibatnya

Dalam hal ini $x_{1}^{*}>0$ jika

$$
\begin{aligned}
& x_{1}^{*}=\frac{-A+\sqrt{A^{2}-4 \mu}}{2} \\
& x_{2}^{*}=\frac{-A-\sqrt{A^{2}-4 \mu}}{2}
\end{aligned}
$$

$$
\begin{gathered}
A<0 \\
\frac{\mu \eta+\sigma \eta-\mu \xi-\mu \sigma \eta}{\sigma \eta}<0 \\
\eta(\mu+\sigma)<\mu(\xi+\sigma \eta)
\end{gathered}
$$

dan $x_{2}^{*}$ dapat ditunjukan bernilai positif. $x_{2}^{*}>0$, jika

$$
-A-\sqrt{A^{2}-4 \mu}>0 \Leftrightarrow A^{2}>A^{2}-4 \mu \text {. }
$$

Selanjutnya jika $x_{1}^{*}, x_{2}^{*}>0$, maka $y_{1}^{*}, y_{2}^{*}>0$.

b) $A^{2}-4 \mu=0$

Jika $A^{2}-4 \mu=0$, maka $\sqrt{A^{2}-4 \mu}=0$. Akibatnya

Dalam hal ini $x^{*}>0$ jika

$$
x^{*}=\frac{-A}{2} \Leftrightarrow x^{*}=\frac{\left(\frac{\mu \sigma \eta+\mu \xi-\mu \eta-\sigma \eta}{\sigma \eta}\right)}{2}
$$

$$
\mu \sigma \eta+\mu \xi-\mu \eta-\sigma \eta>0 \Leftrightarrow \eta(\mu+\sigma)<\mu(\xi+\sigma \eta)
$$

Selanjutnya karena $x^{*}>0$, maka $y^{*}>0$ jika $\eta-\xi>0$.

Dengan demikian $E_{1} \in R^{+}$jika memenuhi syarat $\eta(\mu+\sigma)<\mu(\xi+\sigma \eta)$ dan $\eta>\xi$.

\subsection{Analisis Kestabilan Titik Kesetimbangan} Jacobian.

Kestabilan titik kesetimbangan dapat ditentukan berdasarkan nilai eigen dari matriks

\subsubsection{Matriks Jacobian}


Dinamika model di sekitar $E_{0}$ dan $E_{1}$ dapat dipelajari terlebih dahulu dengan menentukan matriks Jacobian. Matriks Jacobian diperoleh dengan mencari turunan dari persamaan (6). Berdasarkan persamaan (6) diperoleh matriks Jacobian,

$$
J(x, y)=\left[\begin{array}{cc}
1-\frac{2 x}{\mu}-\frac{y}{(1+x)^{2}} & -\frac{x}{1+x} \\
\frac{\eta \sigma y^{2}}{x^{2}} & \eta-\frac{2 \eta \sigma y}{x}-\xi
\end{array}\right]
$$

\subsubsection{Kestabilan $E_{0}$}

Linierisasi di sekitar titik kesetimbangan $E_{0}$ pada persamaan (7) menghasilkan matriks Jacobian untuk titik tetap $E_{0}$ sebagai berikut

$$
J\left(E_{0}\right)=\left[\begin{array}{cc}
-1 & -\frac{\mu}{1+\mu} \\
0 & \eta-\xi
\end{array}\right]
$$

Matriks jacobian pada persamaan (8) selanjutnya dievaluasi untuk menentukan nilai eigen. Dalam hal ini,

$$
J\left(E_{0}\right)-\lambda I=\left[\begin{array}{cc}
-1-\lambda & -\frac{\mu}{1+\mu} \\
0 & \eta-\xi-\lambda
\end{array}\right]
$$

Dari persamaan (9) diperoleh

$$
\begin{array}{r}
\left|J\left(E_{0}\right)-\lambda I\right|=0 \\
\left|\begin{array}{cc}
-1-\lambda & -\frac{\mu}{1+\mu} \\
0 & \eta-\xi-\lambda
\end{array}\right|=0 \\
\lambda_{1}=-1 \text { dan } \lambda_{2}=\eta-\xi
\end{array}
$$

$\lambda_{1}$ jelas bernilai negatif sedangkan $\lambda_{2}$ bernilai negatif jika $\eta<\xi$ yang kontradiktif dengan syarat eksistensi titik kesetimbangan bahwa $\eta>\xi$. Dengan demikian, titik kesetimbangan $E_{0}$ tidak dapat mencapai kondisi stabil.

\subsubsection{Kestabilan $E_{1}$}

Linearisasi di sekitar titik kesetimbangan $E_{1}$ pada persamaan (7) menghasilkan matriks Jacobian untuk titik tetap $E_{1}$ sebagai berikut,

$$
J\left(E_{1}\right)=\left[\begin{array}{cc}
1-\frac{2 x^{*}}{\mu}-\frac{(\eta-\xi) x^{*}}{\eta \sigma\left(1+x^{*}\right)^{2}} & -\frac{x^{*}}{1+x^{*}} \\
y^{*}(\eta-\xi) & \eta-\xi
\end{array}\right]
$$


Matriks jacobian pada persamaan (10) selanjutnya dievaluasi untuk menentukan nilai eigen. Dalam hal ini,

$$
J\left(E_{1}\right)-\lambda I=\left[\begin{array}{cc}
1-\frac{2 x^{*}}{\mu}-\frac{(\eta-\xi) x^{*}}{\eta \sigma\left(1+x^{*}\right)^{2}}-\lambda & -\frac{x^{*}}{1+x^{*}} \\
y^{*}(\eta-\xi) & \eta-\xi-\lambda
\end{array}\right]
$$

Dari persamaan (11) diperoleh

menghasilkan persamaan karakteristik

$$
\left|\begin{array}{cc}
1-\frac{2 x^{*}}{\mu}-\frac{(\eta-\xi) x^{*}}{\eta \sigma\left(1+x^{*}\right)^{2}}-\lambda & \left.-\frac{x^{*}}{1+E^{*}}\right)=0 \\
y^{*}(\eta-\xi) & \eta-\xi-\lambda
\end{array}\right|=0
$$

$$
f(\lambda)=\lambda^{2}+\left(\delta_{1}+\eta-\xi-1\right) \lambda+\left(\delta_{1}+\delta_{2}-1\right)(\eta-\xi)=0
$$

dengan

$$
\delta_{1}=\frac{2 x^{*}}{\mu}+\frac{(\eta-\xi) x^{*}}{\eta \sigma\left(1+x^{*}\right)^{2}} \text { dan } \delta_{2}=\frac{x^{*} y^{*}}{1+x^{*}}
$$

Selanjutnya diperoleh

dengan

$$
\lambda_{1,2}=\frac{-C \pm \sqrt{C^{2}-4 D}}{2}
$$

$$
\begin{aligned}
& C=\left(\delta_{1}+\eta-\xi-1\right)>0 \\
& D=\left(\delta_{1}+\delta_{2}-1\right)(\eta-\xi)>0 .
\end{aligned}
$$

Titik kesetimbangan $E_{1}$ dapat mencapai kondisi stabil jika $\operatorname{Re}\left(\lambda_{1,2}\right)<0$, dengan ketentuan sebagai berikut:

i) Untuk $C^{2}-4 D>0$,

$$
\lambda_{1}=\frac{-C+\sqrt{C^{2}-4 D}}{2}, \quad \lambda_{2}=\frac{-C-\sqrt{C^{2}-4 D}}{2}
$$

Dalam hal ini, $\operatorname{Re}\left(\lambda_{1,2}\right)<0$ dapat ditunjukkan kebenaranya.

$\lambda_{1}<0$ jika $-C+\sqrt{C^{2}-4 D}<0 \Leftrightarrow C^{2}<C^{2}-4 D$.

$\lambda_{2}<0$ jika $-C-\sqrt{C^{2}-4 D}<0$. Karena $C^{2}-4 D>0$, maka jelas bahwa $\lambda_{2}<0$.

ii) Untuk $C^{2}-4 D<0$,

$$
\lambda_{1,2}=\frac{-C \pm\left(C^{2}-4 D\right) i}{2}
$$

yang menunjukkan bahwa $\operatorname{Re}\left(\lambda_{1,2}\right)<0$.

iii) Untuk $C^{2}-4 D=0$,

$$
\lambda_{1,2}=\frac{-C}{2}<0 .
$$


Dengan demikian, titik kesetimbangan $E_{1}$ dapat mencapai kondisi stabil dengan memenuhi syarat eksistensi kesetimbangan, yaitu $\eta(\mu+\sigma)<\mu(\xi+\sigma \eta)$ dan $\eta>\xi$.

\subsection{Simulasi Numerik}

Pada bahasan ini, dilakukan simulasi numerik untuk melihat dinamika model di sekitar titik-titik kesetimbangan dan efek pemberian racun terhadap populasi predator.

\subsubsection{Simulasi Numerik $E_{0}$}

Dari persamaan (6), diperoleh titik kesetimbangan $E_{0}=(\mu, 0)$. Kondisi kestabilan dan dinamika populasi untuk titik kesetimbangan $E_{0}$ dapat dilihat dengan melakukan simulasi menggunakan nilai-nilai parameter pada Tabel 1.

Tabel 1: Nilai Parameter untuk Simulasi $\boldsymbol{E}_{\mathbf{0}}$

\begin{tabular}{|c|c|c|c|l|c|}
\hline Kondisi & $\boldsymbol{\mu}$ & $\boldsymbol{\sigma}$ & $\boldsymbol{\eta}$ & \multicolumn{1}{c|}{$\boldsymbol{\boldsymbol { E } _ { \mathbf { 0 } } = ( \boldsymbol { \mu } , \mathbf { 0 } )}$} \\
\hline 1 & 0.9 & 0.2 & 0.3 & 0 & $(0.9,0)$ \\
\hline 2 & 0.9 & 0.2 & 0.3 & 0.15 & $(0.9,0)$ \\
\hline 3 & 0.9 & 0.2 & 0.3 & 0.29 & $(0.9,0)$ \\
\hline
\end{tabular}

Ketiga kondisi pada Tabel 1 menggunakan nilai awal yang disajikan pada Tabel 2.

Tabel 2: Nilai Awal untuk Simulasi $\boldsymbol{E}_{\mathbf{0}}$

\begin{tabular}{|l|l|l|l|l|}
\hline$x$ & 1.5 & 0.2 & 0.2 & 1.5 \\
\hline$y$ & 0.01 & 0.01 & 0.03 & 0.03 \\
\hline
\end{tabular}

Selanjutnya diperoleh plot grafik untuk melihat dinamika dari setiap populasi. Dinamika populasi di titik kesetimbangan $E_{0}$ disajikan pada Gambar 1 . 


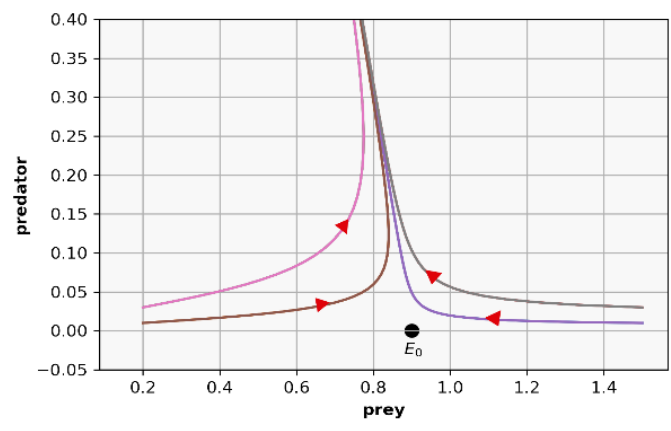

(a)

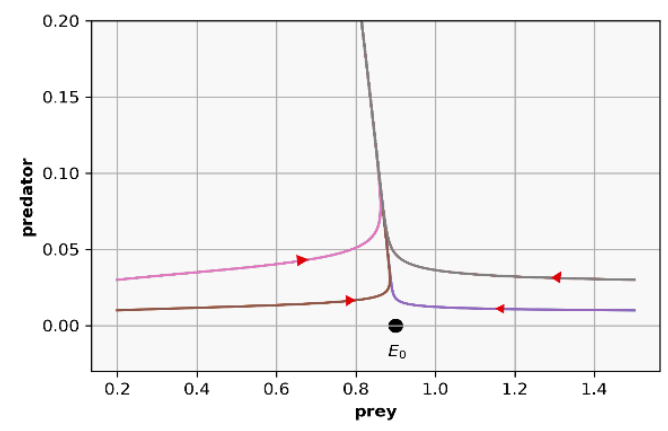

(b)

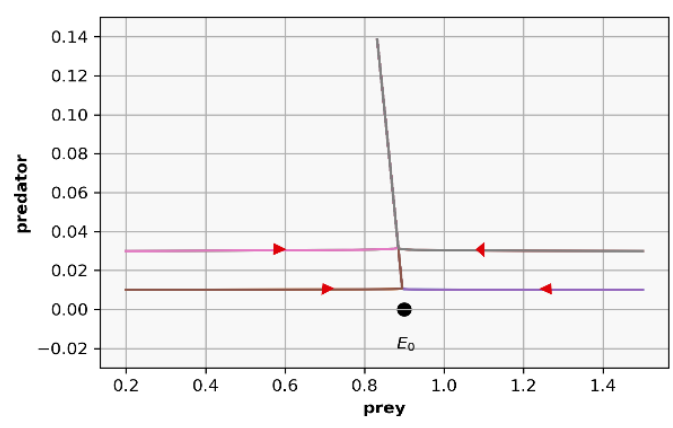

(c)

Gambar 1: Dinamika Populasi untuk Titik Kesetimbangan $\boldsymbol{E}_{\mathbf{0}}$

Simulasi yang ditampilkan pada Gambar 1 menunjukkan tiga kondisi. Kondisi (a) menunjukkan tidak adanya racun yang diberikan pada predator $(\xi=0)$, kondisi (b) menunjukkan banyaknya racun yang di berikan pada predator setengah dari laju pertumbuhan intrinsik predator $(\xi=0.15)$ dan kondisi (c) menunjukkan banyaknya racun yang di berikan pada predator hampir mendekati laju pertumbuhan intrinsik predator $(\xi=0.29)$. Populasi predator pada titik ini mengalami kepunahan. Gambar 1 memperlihatkan dinamika disekitar titik $E_{0}$ yang tidak stabil saddle. Kedua populasi awalnya bergerak menuju $E_{0}$ kemudian menjauh setelah berada di sekitar titik $E_{0}$.

\subsubsection{Simulasi Numerik $E_{1}$}

Dari persamaan (6), diperoleh titik kesetimbangan $E_{1}=\left(x^{*}, y^{*}\right)$. Titik $E_{1}$ dikatakan stabil jika memenuhi syarat kestabilan untuk $D_{\lambda}>0$ dan $D_{\lambda}<0$. Kondisi kestabilan dan dinamika populasi untuk titik kesetimbangan $E_{1}$ dapat dilihat dengan melakukan simulasi menggunakan nilai-nilai parameter pada Tabel 3.

Tabel 3: Nilai Parameter untuk Simulasi $\boldsymbol{E}_{1}$

\begin{tabular}{|c|c|c|c|l|c|}
\hline Kondisi & $\boldsymbol{\mu}$ & $\boldsymbol{\sigma}$ & $\boldsymbol{\eta}$ & $\boldsymbol{\xi}$ & $\boldsymbol{E}_{\mathbf{0}}=(\boldsymbol{\mu}, \mathbf{0})$ \\
\hline 1 & 0.5 & 0.31 & 0.1 & 0 & $(0.2148,0.6929)$ \\
\hline 2 & 0.5 & 0.31 & 0.1 & 0.05 & $(0.3094,0.4990)$ \\
\hline 3 & 0.5 & 0.31 & 0.1 & 0.09 & $(0.4499,0.1451)$ \\
\hline
\end{tabular}

Berdasarkan nilai-nilai parameter pada Tabel 3, diperlihatkan dinamika populasi populasi Predator dan Prey. Dinamika yang terjadi antara kedua populasi ditunjukkan pada Gambar 2. 


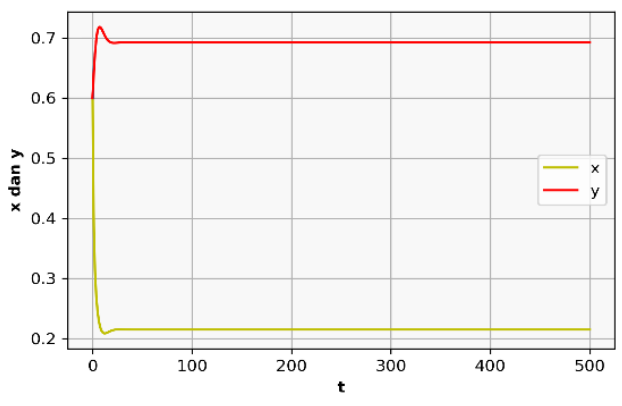

(a)

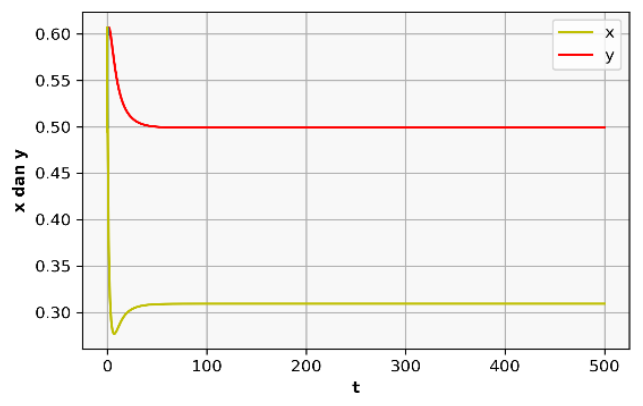

(b)

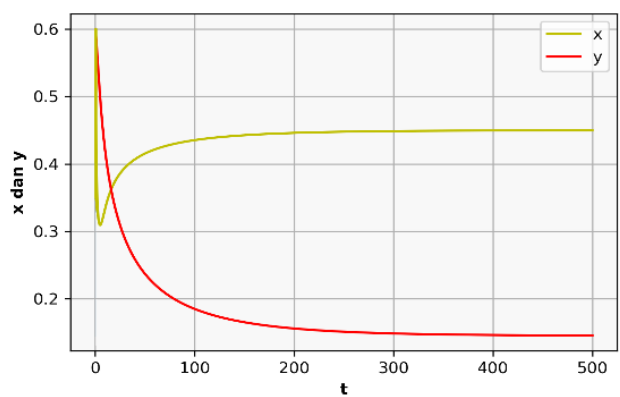

(c)

Gambar 2: Dinamika Populasi Predator-Prey pada Titik Kesetimbangan $\boldsymbol{E}_{\mathbf{1}}$

Dinamika yang terjadi pada Gambar 2 menunjukan tiga kondisi. Kondisi pertama menunjukkan tidak adanya racun yang di berikan pada predator $(\xi=0)$, kondisi kedua menunjukkan banyaknya racun yang di berikan pada predator adalah setengah dari laju pertumbuhan intrinsik predator $(\xi=0.05)$ dan kondisi ketiga menunjukkan banyaknya racun yang di berikan pada predator hampir mendekati laju pertumbuhan intrinsik predator $(\xi=0.09)$. Gambar 2 menunjukkan bahwa setiap variabel akan konstan menuju ke suatu titik yang artinya laju pertumbuhan populasi predator-prey sudah mencapai kondisi stabil. Pada ketiga kondisi tersebut, populasi kedua spesies tidak punah.

Selanjutnya, untuk melihat dinamika dari setiap populasi pada ketiga kondisi tersebut digunakan nilai awal pada Tabel 4.

Tabel 4: Nilai Awal untuk Simulasi $\boldsymbol{E}_{\mathbf{1}}$ pada Kondisi Stabil dengan $\boldsymbol{D}_{\lambda}>\mathbf{0}$

\begin{tabular}{|l|l|l|l|l|}
\hline$x$ & 0.1 & 0.6 & 0.4 & 0.7 \\
\hline$y$ & 1.75 & 0.55 & 1.7 & 1.1 \\
\hline
\end{tabular}

Dinamika populasi untuk titik kesetimbangan $E_{1}$ pada kondisi stabil dengan $D_{\lambda}>0$ disajikan pada Gambar 3. 


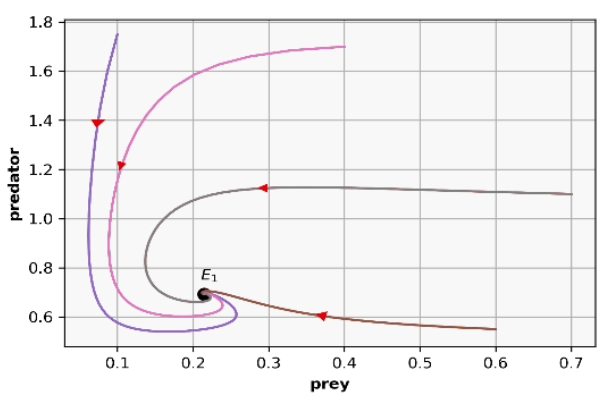

(a)

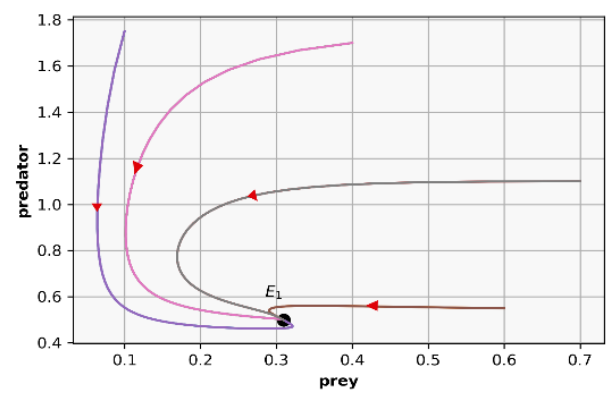

(b)

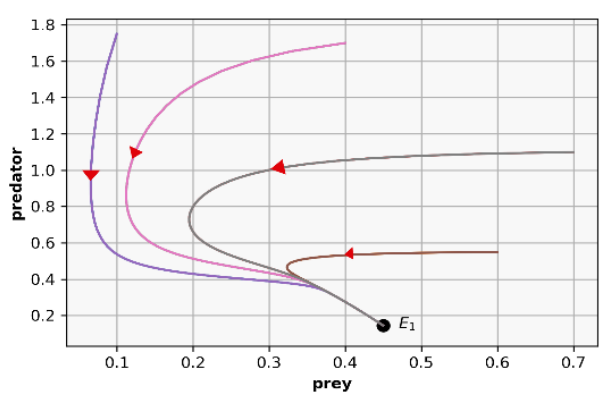

(c)

Gambar 3: Dinamika Populasi untuk $\boldsymbol{E}_{\mathbf{1}}$ pada kondisi stabil dengan $\boldsymbol{D}_{\lambda}>\mathbf{0}$

Gambar 3 menunjukkan dinamika populasi predator-prey yang bergerak menuju titik $E_{1}$ dan stabil di titik tersebut.

Selanjutnya, kondisi kestabilan dan dinamika populasi titik kesetimbangan $E_{1}$ untuk $D_{\lambda}<0$ dapat dilihat dengan melakukan simulasi menggunakan nilai parameter pada Tabel 5.

Tabel 5: Nilai Parameter untuk Simulasi $\boldsymbol{E}_{\mathbf{1}}$ dengan $\boldsymbol{D}_{\lambda}<\mathbf{0}$

\begin{tabular}{|c|c|c|c|c|c|}
\hline Kondisi & $\boldsymbol{\mu}$ & $\boldsymbol{\sigma}$ & $\boldsymbol{\eta}$ & $\boldsymbol{\xi}$ & $\boldsymbol{E}_{\mathbf{1}}=\left(\boldsymbol{x}^{*}, \boldsymbol{y}^{*}\right)$ \\
\hline 1 & 0.5 & 0.2 & 0.2 & 0 & $(0.1583,0.7916)$ \\
\hline 2 & 0.5 & 0.31 & 0.1 & 0.05 & $(0.2247,0.6742)$ \\
\hline
\end{tabular}

Kedua kondisi ini dismulasikan dengan menggunakan nilai awal pada Tabel 6.

Tabel 6: Nilai Awal untuk Simulasi $\boldsymbol{E}_{\mathbf{1}}$ pada Kondisi Stabil dengan $\boldsymbol{D}_{\boldsymbol{\lambda}}<\mathbf{0}$

\begin{tabular}{|l|l|l|l|l|}
\hline$x$ & 0.6 & 0.1 & 0.7 & 0.7 \\
\hline$y$ & 1.75 & 1.6 & 1.4 & 1.1 \\
\hline
\end{tabular}

Selanjutnya, dinamika populasi untuk titik kesetimbangan $E_{1}$ pada kondisi stabil dengan $D_{\lambda}<0$ disajikan pada Gambar 4. 


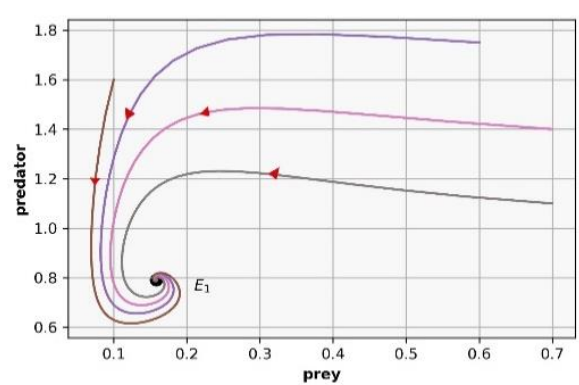

(a)

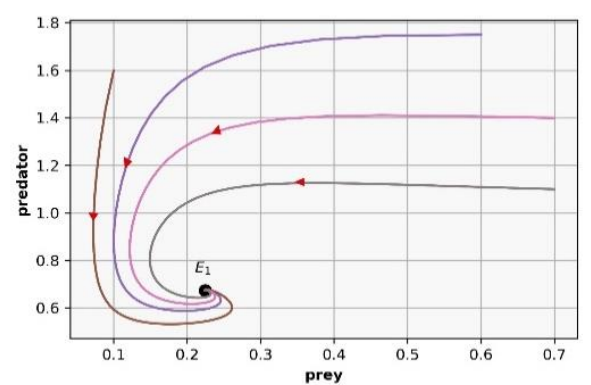

(b)

Gambar 4: Dinamika Populasi untuk $\boldsymbol{E}_{\mathbf{1}}$ pada kondisi stabil dengan $\boldsymbol{D}_{\boldsymbol{\lambda}}<\mathbf{0}$

Simulasi yang ditunjukkan pada Gambar 4 menunjukkan dinamika populasi pada dua kondisi. Kondisi (a) menunjukkan tidak adanya racun yang di berikan pada predator $(\xi=0)$, dan kondisi (b) yang menunjukkan banyaknya racun yang di berikan pada predator adalah sebesar $\xi=0.08$. Pada kedua kondisi tersebut, populasi predator-prey tidak mengalami kepunahan. Gambar 4 menunjukkan bahwa populasi predator-prey bergerak menuju titik $E_{1}$ dan mencapai kondisi stabil di titik tersebut.

\section{Kesimpulan}

Titik kesetimbangan $E_{0}$ tidak dapat mencapai kondisi stabil, sedangkan titik kesetimbangan $E_{1}$ mencapai kondisi stabil apabila memenuhi syarat eksistensi titik kesetimbangan, yaitu $\eta(\mu+\sigma)<\mu(\xi+\sigma \eta)$ dan $\eta>\xi$.

\section{Referensi}

[1] Aftyah, S.N., 2015, 'Analisis Dinamik Model Predator-Prey Leslie-ttower dengan Fungsi Respon Holling Tipe II'. Jurnal Ilmiah Teknologi dan Informasia ASIA (JITIKA), Vol. 9, No. 2.

[2] Panigoro, H.S., Rahmi, E., 2017, Modifikasi Sistem Predator-Prey: Dinamika Model Leslie-ttower dengan Daya Dukung yang Tumbuh Logistik, SEMIRATA MIPA, UNSRAT, Manado.

[3] Leslie, P. H. 1948, 'Some Further Notes on the Use of Matrices in Population Mathematics', Oxford University Press, Biometrika, Vol. 35.

[4] Sholeh, M., Kholipah, S., 2013, 'Model matematika mangsa-pemangsa dengan sebagian mangsa sakit', Jurnal Sains, Teknologi dan Industri, Universitas Islam Negeri Sultan Syarif Kasim Riau, Vol. 10 No. 2.

[5] Keong, A.T., Safuan, H.M., Jacob, K., 2018,'Dynamical Behaviours of Prey-predator Fishery Model with Harvesting Affected by Toxic Substances', Universiti Tun Hussein Press, Volume 34.

[6] N. Hasan, R. Resmawan, and E. Rahmi, “Analisis Kestabilan Model Eko-Epidemiologi dengan Pemanenan Konstan pada Predator," J. Mat. Stat. dan Komputasi, vol. 16, no. 2, pp. 121-142, Dec. 2020.

[7] H. S. Panigoro, E. Rahmi, N. Achmad, and S. L. Mahmud, "The Influence of Additive Allee Effect and Periodic Harvesting to the Dynamics of Leslie-Gower Predator- Prey 
Model," Jambura J. Math., vol. 2, no. 2, pp. 87-96, 2020.

[8] Braun, M., 1978, Differential Equation and Their Applications, New York, SpringerVerlag.

[9] Perko, L., 1991, Differential Equation and Dynamical System, New York, SpringerVerlag Berlin Heidelberg.

[10] Wiggins, S., 2003, Introduction to Applied Nonlinear Dynamical System and Chaos, Second Edition, New York, Springer-Verlag.

[11] Anton, H., 1991, Aljabar Linear Elementer, Jakarta, Erlangga.

[12] Edelstein-Keshet, L., 1998, 'Mathematical Models in Biology', Society for Industrial and Applied Mathematics, Philadelphia, PA 19104.

[13] Barnes, B., Fulford, G.R., 2002, Mathematical Modelling with Case Studies (a Differential Equation Approach Using Maple), London, Taylor and Francis.

[14] Berryman, A., 1992, Ecology, Ecologi society of America.

[15] Boyce, W.E., DiPrima, R.C., 2001, Elementary Differential Equations and Boundary Value Problems, New York, John Wiley and Sons.

[16] Skalski, G.T., Gilliam J.F., 2001, 'Functional Respons with Predator Interference: Viable Alternatives to the Holling Type II Model', Ecology, 82: 3083-3092.

[17] Ndam, J.N., Kaseem T.G., 2009, Stability of Dinamical Systems, Elsevier, Netherlands.

[18] Edelstein-Keshet, L., 2005, Mathematical Models in Biology, New York, Random House. 